Journal

of Geography,

Politics and Society

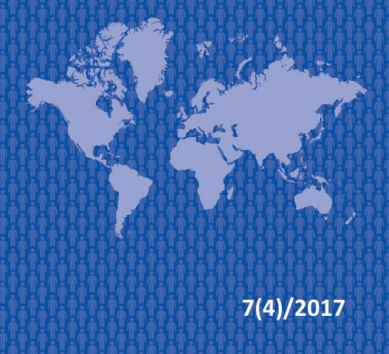

\section{Journal of Geography, Politics and Society}

$2017,7(4), 41-45$

DOI 10.4467/24512249JG.17.036.7636

\title{
THE IMPLEMENTATION OF THE STATE SOCIAL POLICY IN UKRAINE AND ABROAD: METHODOLOGICAL APPROACHES TO ASSESSMENT OF EFFECTIVENESS
}

\author{
Alina Leonidivna Pomaza-Ponomarenko \\ Scientific Department of Problems on State Security of Educational-Scientific-Production Center, National University of Civil Protection of Ukraine, \\ Lermontovska 28, 61024 Kharkiv, Ukraine, \\ e-mail:a_pp_l@i.ua
}

\section{Citation}

Pomaza-Ponomarenko A.L., 2017, The implementation of the state social policy in Ukraine and abroad: methodological approaches to assessment of effectiveness, Journal of Geography, Politics and Society, 7(4), 41-45.

\begin{abstract}
The analysis of the condition of financial support of the state social policy in the economically developed countries and in Ukraine was made. The idea about the influence of the GDP growth rates dynamics on the share of social expenditures of these states was expressed and verified. It was defined that a relatively stable and high level of government social expenditures (nearly 20 percent) is achieved after several medium-term economic cycles, after which the economic system adapts to market relations, and the stabilization of social expenditures occurs. It makes it possible to assert that there is a certain optimum of the level of social expenditures, and the state aims to maintain it after its achievement. This level of expenditures ensures the implementation of the main goals of the state social policy.
\end{abstract}

\section{Key words}

regional systems of Ukraine, object of state management, academic mobility, the concept of public administration in Ukraine, development trends.

Received: 22 November 2016 Accepted: 13 June 2017 Published: 29 December 2017

\section{Introduction}

There is no country with a highly developed economy, which would be eliminated from the regulation of key social and economic processes (Дмитрук, 2012). Therefore, the implementation of scientific and methodological characteristics of the features of public administration practice to ensure the steady social development abroad with the aim of its use in Ukraine is actual.
It should be noted, that there is the growing of interest and attention of scientists (P. Dmytruk, N. Starostenko, O. Saienko, V. Kolosova, N.Slynko etc. (Дмитрук, 2012; Старостенко et al., 2014)) to the matters of the state policy to ensure social development.

However, the search for the optimal model for this development necessitates the realization of further research and methodological development works to determine the most effective scenarios of the implementation of the state social policy taking 
into account a number of objective and subjective factors that affect it.

Therefore, the purpose of the article is the study of the modern state of the financial provision of the state social policy abroad and in Ukraine, and also the study of the methodological approaches to evaluating of the effectiveness of the implementation of such policy.

\section{Effectiveness and assessment of the state social policy}

The study of the socio-economic dynamics and its impact on the functioning of the state social policy allows us to determine the modern trends of its development and, therefore, to consider its cycling, if it is available. It is a relevant observation of a number of scientists (N. Starostenko, O. Saienko, V. Kolosova, N. Slynko, A. Degtyar, O. Degtyar, V. Covalchuk, I. Gritsyak, D. Dzvinchuk, M. Arakelyan, O. Vishnyakova etc.) (Старостенко et al., 2014; Дєгтяр et al., 2015; Грицяк, Дзвінчук, 2013; Аракелян, Вишнякова, 2010) that the dynamics of the economy directly depends on the innovation and social progress, that is, on the one hand, accompanied by the significant spending, investment, and, on the other hand, it can generate the cyclical fluctuations.

The study of this impact requires the implementation of the generalization, which is achieved by the empirical data on the development of the socioeconomic systems.

We believe that the information base of this research can be data, such as the Organization for Economic Cooperation and Development, which are grouped by it with respect to the countries within a particular model of their development.

During the World Economic Forum in Davos in 2015, the desire (including by the Organization for Economic Cooperation and Development (OECD..., 2016)) was expressed concerning the deepening of the cross-border cooperation with Ukraine, the importance of adaptation of the best global practices (in the context of the modernization of its public administration system), which such Organization has mastered for it.

The development of the state social policy is determined by the economic evolution (Дєгтяр et al., 2015). There is the hypothesis, that it can be expressed in the growth / decline of the government social activity and orientation by the growth / decline of the amounts of government social support and «financial scope» of the relevant social programs.

This hypothesis requires the verification of several assumptions and scenarios, namely: in any cycles (short, medium or long-term) the fluctuations of the economic activity affect the state social policy, determining the amount of government expenditures.

We believe that it is possible to carry out such verification of the hypothesis, first, by the comparing of the dynamics of change of the share of government expenditures in the social sector (we are talking about the education, health, pensions accounts and other social payments etc.), and secondly, by the providing a comparison of the dynamics of change of the share of government expenditures and GDP per capita.

The Organization for Economic Cooperation and Development singled out several models of the state social policy, given the impact of the economic processes taking place in one or another country (OECD..., 2016).

However, this definition of the flexibility of government social expenditures depending on the state of economy and the change of paces of its development is beneficial in the medium and long term perspective.

We believe that it is possible to evaluate, including perspective view on the financial support of the state social policy in the long term also using the regulations of national social programs. They are an original indicator of the quantitative characteristics of this policy.

It should be noted, that the dynamics of the state social policy can be represented as the changing of the amount, directions and volume of the implementation of the social measures.

The practice of its (dynamics) determination shows that mathematically it can be expressed in the light of change of the share of government social expenditures in the gross domestic product.

However, the dynamics of the economic development is largely reflected in the growth rates of real GDP and in the objective laws of fluctuations in the economic activities.

In addition, the inclusion in the analysis of the state social policy and other meaningful information indicator - the growth rates of GDP per capita is common (OECD..., 2016).

Based on the empirical data concerning the development of social and economic systems of the Organization for Economic Cooperation and Development (OECD..., 2016) during the period from 1985 to 2015 can be achieved corresponding calculation, characteristics and prognosis of the general laws of evolution of the modern world economy, and assessed their impact on the development of the state social policy. This period (1985-2015) was named of Kondratievskyi's (Дегтяр et al., 2015). 
In XX century the critical phases synchronicity of the national and global cycles was established, as a result, the market cycles and the economic development cycles have actually coincided.

It allows to design the trends, found in some countries, of the total world economy influence. It is obvious that the long waves (especially Kondratievska's) of the economic and social development are derived from the medium and short ones.

The analysis of the information-analytical material (OECD..., 2016) suggests that the share of government social expenditures in GDP of the Organization for Economic Cooperation and Development countries made up almost 16\% (in 1985) and in 1995 it was its growth and stabilization within $20 \%$.

In this way the phases of the economic cycle during the 1985-2015 years performed moderate impact on the intensity of financial expenditures on the implementation of the social programs in the Organization for Economic Cooperation and Development countries.

The Organization for Economic Cooperation and Development conducted comparing and conventionally singled out several groups of countries that meet such models of the state social policy as (OECD..., 2016):

a) the Anglo-Saxon model, which includes the US, Canada and England;

b) the European model is presented by the EU countries;

c) the Scandinavian model, which is formed by Norway, Sweden, Finland;

d) the East Asian model, it includes Japan, South Korea, Hong Kong, Singapore;

e) the "post-Soviet model" is formed by Hungary, Poland, Russia, Czech Republic, Slovakia and Ukraine.

The consideration of the growth rates of real GDP, GDP per capita and the share of government social expenditures in countries that have adopted AngloSaxon model, allows to determine the following regularities: in the US the growth rates of the economy as a whole from 1985 to 2015 were in the range of $15 \%$ and do not exceed the same indicators calculated in relation to all the countries in the Organization for Economic Cooperation and Development.

As for the share of government social expenditures in GDP in the US, it was consistently at the level of $10-15 \%$ (with an average median value of $15 \%)$.

In addition to that the significant dependence of the intensity of the implementation and financing of the government social programs in relation to the economic activitiess, as well as the relatively low share of government social expenditures is characterized for the United States.

It occurs to the existing of the advanced feedback mechanism established during the formation and implementation of the state social policy, which is weighted by the solution of problems of the social protection and development and rapid response to changes in the state economy.

Almost a similar situation was in England. However, during the test period the share of government social expenditures in GDP of this country was on average $2-4 \%$ higher than in the US. On the one hand, it undoubtedly indicates the special place of this country in the Anglo-Saxon group, on the other hand, it can be attributed to the economic system of England to the European group of countries singled out by the Organisation for Economic Cooperation and Development.

It should be noted that during the analyzable period in Germany the government social expenditures remain the relatively stability (ranging around $25 \%$ of GDP mark). In France, a similar value was reached in 1990, but since 1999, the state has come close to $30 \%$, that is typical, especially, Scandinavian model (Аракелян, Вишнякова, 2010; OECD..., 2016).

Sweden has the typical features of the Scandinavian model of the state social policy. In it during 1985-2015 years it's observed the conservation the same level of the indicator of the share of government social expenditures in GDP, namely $28-30 \%$.

A similar situation can be seen in the economy of Finland, where the range of the share of these expenditures amounted to $20-35 \%$ in the test period. Interestingly, the economy of Sweden and Finland to the significant slowdown of economic growth rates in the world (in 2008) responded to the relative increase in social expenditures.

A separate group is constituted by the East Asian model of the state social policy countries. In this model, Japan ranks a special place. By 1993, it was inherent in some reduction of the economic growth rates dynamics along with the large range of the fluctuations (from 5\% to 20\%), compared with European countries. However, this situation is accompanied by the sustained value of the share of government social expenditures in GDP (OECD..., 2016).

In respect of the post-Soviet countries, it is highlighted because of the following: in the middle of the twentieth century the USSR managed to achieve $20 \%$ of government social expenditures in quite a short time and to keep this figure of social 
guarantees providing at a high level for 30 years (Дмитрук, 2012; Дєгтяр et al., 2015; Грицяк, Дзвінчук, 2013).

Therefore, this precedent in the world economic history was called the "Soviet model of the state social policy". The research of the socio-economic development in the post-socialist countries is somewhat complicated.

As the formation of market relations some of which has not yet occurred, so the value of macroeconomic indicators can not be measured in the same manner as in the countries with the sustained socio-economic development.

In addition, the existing difficulties regarding the use of the methods of calculation of macroeconomic indicators, because they are different from those which used in other countries. However, the performance of a number of objective and subjective factors brings the trends of the development of the social policy of the post-socialist European countries.

As for Ukraine, its budget priorities differ substantially from those which are in the member countries of the Eurozone, particularly for all of the expenditures on health, education, pensions, unemployment benefits, social benefits of accidents at work and occupational diseases, etc. (tab. 1.).

Allow for the State Statistics Service of Ukraine data (База..., 2016), we can insist that our state largely exceeded the expenditures on social protection and ensuring, in comparison with the countries of the EU-28, in which they amount to $1.9 \%$ of GDP.

The share of these expenditures in Ukraine is almost half of the total dimension and amounts to $6.5 \%$ of GDP. The spending such significant amounts of financial resources for the implementation of the state social functions leads to the formation of the budget «eating away».
However, this expenditure policy can be afford by those countries that have introduced the system of state social insurance.

Given of the global trend of population ageing and the migration of a significant number of ablebodied population of Ukraine abroad, the continuation of current budget policy is invalid because it compels to increase the share of social expenditures. So in the near future it may adversely affect the financial stability of Ukraine and the pace of development of its economy.

\section{Conclusions of the research}

Therefore, after analyzing the dynamics of GDP growth and the share of social expenditures in the economically developed countries (the USA, EU, Near East, etc.) and the post-socialist countries we can claim that the hypothesis about the existence of dependencies between these indicators and the cyclical nature in the development of the state social policy can be confirmed only partially.

Because of during the recession of the average wave of economic cycle, there is a slight increase in the share of social expenditures (in fact, its social activity). In the economically developed countries it mainly can last $1-2$ years.

The presence of such time limitation is accounted for the fact that public authorities need the time to assess and adjust their expenditure policy to minimize the negative effects of the slowdown in the economic growth.

As for Ukraine, it is possible to predict the development of social policy in two ways - positive (activity) and negative (inertial). If Ukraine's economy will grow by inertia, it is expected the increase of social expenditures. In this case, there is the significant probability that the increase of the quality and

Tab. 1. Structure of government expenditures in the European Union countries and Ukraine (by structural-functional classification in 2014)

\begin{tabular}{|l|l|c|c|c|c|}
\hline \multirow{2}{*}{ № } & \multirow{2}{*}{$\begin{array}{c}\text { Sector, to the support of which the government } \\
\text { funds are appropriated }\end{array}$} & \multicolumn{2}{|c|}{ EU-28 } & \multicolumn{2}{c|}{ Ukraine } \\
\cline { 3 - 6 } & & \% of GDP & $\%$ & \% of GDP & \% \\
\hline 1 & Social protection and ensuring & 19.6 & 39.9 & 14.5 & 28.0 \\
\hline 2 & Health & 13.9 & 24.4 & 13.1 & 22.7 \\
\hline 3 & Education, recreation, culture and religion & 6.4 & 17.1 & 5.2 & 14.0 \\
\hline 4 & Economic affairs & 4.0 & 8.2 & 3.8 & 7.5 \\
\hline 5 & Defence, public order and safety & 3.1 & 6.9 & 12.9 & 23.9 \\
\hline 6 & Housing and community amenities & 0.9 & 1.7 & 1.1 & 3.1 \\
\hline 7 & Environmental protection & 0.9 & 1.7 & 0.4 & 0.8 \\
\hline 8 & Total & 49.1 & 100.0 & 51.0 & 100.0 \\
\hline
\end{tabular}

Sources: it's compiled on the basis of: База..., 2016; Старостенко et al., 2016; OECD..., 2016; Дєгтяр еt al., 2015. 
standard of living does not happen in a few medium-term cycles.

The comparing of the parameters can also define that relatively stable and high level of government social expenditures (20\%) is achieved the conditions of the path of several medium-term economic cycles.

In their range the adapting of the economic system to the market economy exists, as well as the government assuring of declared social guarantees.

This trend covers a specific definition of the optimum for the implementation of social policy and government social expenditures. Having achieved this optimal level, one or another country tends to keep it, because it contributes to the effective and balanced implementation of the basic social functions of the state.

\section{References}

OECD Factbook 2016: Economic, Environmental and Social Statistics, 2016, OECD, Paris, http://www.iberglobal.com/ files/2016/oecd_factbook_15_16.pdf [31.10.2016].

Аракелян М., Вишнякова О., 2010, Право Європейського Союзу, Видавництво «Істина», Київ.

База даних Державної служби статистики України, http:// www.ukrstat.gov.ua/ [31.10.2016].

Грицяк І., Дзвінчук Д., 2013, Європейська інтеграчія, 2013, Видавництво «Місто НВ», Івано-Франківськ.

Дєгтяр О., Дєгтяр А., Степанов В., Ковальчук В., 2015, Державне та регіональне управління в сочіальній сфері, Видавництво «С.А.М.», Харків.

Дмитрук П.М., 2012, Особливості зарубіжної практики забезпечення безпеки в сочіально-економічній сфері, http://www.academy.gov.ua/ej/ej12/txts/10dpmses.pdf [01.11.2016].

Старостенко Н., Саєнко О., Колосова В., Слинько Н., 2014, Бюджетна підтримка ЄС в Україні, Видавництво ФОП Москаленко О.М., Київ. 